\title{
Thoracoscopic Lobectomy and Segmentectomy in Children
} Çocuklarda Torakoskopik Lobektomi ve Segmentektomi

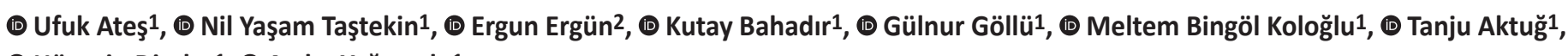
(1) Hüseyin Dindar ${ }^{1}$, (1) Aydın Yağmurlu ${ }^{1}$

${ }_{1}^{1}$ Ankara University School of Medicine, Department of Pediatric Surgery, Ankara, Turkey

2Sami Ulus Children's Hospital, Clinic of Pediatric Surgery, Ankara, Turkey

\section{Abstract}

Objectives: In the last decade, video-assisted thoracoscopic surgery (VATS) is gaining broad popularity in pediatric surgery. The purpose of this study is to analyze the clinical and histopathological results of VATS in pediatric population in a minimum 1-year follow-up period.

Materials and Methods: All patients undergoing an elective lobectomy or segmentectomy with VATS were enrolled for the study. Medical charts of the enrolled patients were retrospectively evaluated and the data of the patients who met the inclusion criteria were extracted for the final analysis. Patients' demographics including gender and age, indications for VATS and past surgical history, preoperative investigations, comorbidities, intraoperative findings, operative data, postoperative course including any morbidity and mortality were recorded.

Results: There were 26 patients (13 males, 13 females). The main indication for VATS was congenital pulmonary airway malformation (10 patients). There were only two segmentectomies. The remaining 24 patients had undergone lobectomies. Only two patients had multi-lobectomies. In four patients, conversion to thoracotomy was required because of bleeding and inadequate exposure. The mean operation time was 107 mins. Chest tube was placed in all of the patients and removed between the postoperative $2^{\text {nd }}$ and $10^{\text {th }}$ days (median=4 days) and the average discharge time was 5.7 days (3-12 days).

Conclusion: VATS is a safe and effective surgical procedure not only for the adults but also for the pediatric population. It has low complication rates with faster recovery time especially for the pediatric cases that have malignancies.

Key Words: Child, Lobectomy, Minimal Invasive Surgery, Segmentectomy, Thoracoscopy

\section{Öz}

Amaç: Video yardımlı torakoskopik cerrahi (VATS), çocuk cerrahisinde son on yılda büyük popülerlik kazanmıştır. Bu çalışmanın amacı, pediyatrik popülasyonda VATS'nin klinik ve histopatolojik sonuçlarını minimum 1 yıllık takip süresinde analiz etmektir.

Gereç ve Yöntem: VATS ile elektif lobektomi veya segmentektomi yapılan tüm hastalar çalışmaya alındı. Kayıtlı hastaların tıbbi çizelgeleri retrospektif olarak değerlendirildi ve dahil edilme kriterlerini karşılayan hastaların verileri analiz için çıkarıldı. Hastaların cinsiyet, yaş, VATS ve geçirilmiş cerrahi öykü endikasyonları, preoperatif incelemeler, komorbiditeler, intraoperatif bulgular, operatif veriler, herhangi bir morbidite ve mortalite dahil olmak üzere postoperatif seyri içeren demografik özellikleri kaydedildi.

Bulgular: Çalışmaya 26 hasta (13 erkek, 13 kadın) dahil edildi. VATS için konjenital pulmoner hava yolu malformasyonu (10 hasta) ana endikasyondu. Sadece iki hastaya segmentektomi yapıldı. Kalan 24 hastaya lobektomi uygulandı. Sadece iki hastada multi-lobektomi yapıldı. Dört hastada kanama ve yetersiz görüş olması nedeniyle torakotomiye dönüldü. Ortalama ameliyat süresi 107 dakika idi. Tüm hastalara göğüs tüpü koyuldu ve ameliyat sonrası 2-10 gün (ortanca=4 gün) içerisinde çekildi ve ortalama taburcu süresi 5,7 gün (3-12 gün) idi.

Sonuç: VATS, sadece yetişkinler için değil aynı zamanda çocuklar için de güvenli ve etkili bir cerrahi işlemdir. Özellikle malignitesi olan pediyatrik hastalarda komplikasyonu düşük, iyileşme süresi daha hızlı olan bir yöntemdir.

Anahtar Kelimeler: Çocuk, Lobektomi, Minimal İnvaziv Cerrahi, Segmentektomi, Torakoskopi

Address for Correspondence/Yazışma Adresi: Assoc. Dr. Gülnur Göllü, MD,

Ankara University School of Medicine, Department of Pediatric Surgery, Ankara, Turkey

Phone: +90 5055025697 E-mail: drggollu@yahoo.com ORCID ID: orcid.org/0000-0001-8163-2226

Received/Geliş Tarihi: 27.10.2019 Accepted/Kabul Tarihi: 23.12.2019

๑Copyright 2020 Ankara University Faculty of Medicine

Journal of Ankara University Faculty of Medicine is published by Galenos Publishing House.

All content are under CC BY-NC-ND license. 


\section{Introduction}

With the development of the new technologies from early 1990s, less-invasive surgical procedures have been described in the pediatric surgery literature in regard to achieve less morbidity and mortality. Video assisted thorcoscopic surgery (VATS) is one of these developments commonly used in pediatric surgery in the last decade (1-3).

The thoracoscopic surgical approach in children and adolescents was first introduced by Rodgers et al. (4) in 1979. Since then, "thoracoscopy" as a minimally invasive surgery, has been widely accepted as a strategy for establishing quick diagnosis and treatment due to its feasibility and safety (57). Nevertheless, it has not gained a widespread use in clinical practice. Although the major advantage of VATS is its minimal invasive approach to the thorax, it has still some disadvantage regard to long learning curve, availability of instruments and potential hazardous intraoperative complications. As a result, the literature contains scarce and inconclusive data about the efficacy and the success of VATS in pediatric population $(8,9)$.

The indications for VATS in pediatric surgery vary in wide range from simple lung biopsies to major lobectomies for malignancies. Lobectomy by VATS has been controversial in terms of its indications, but its efficacy of managing lung diseases in children is well established (10-12). VATS lobectomy was first introduced in the 1990s and has subsequently been demonstrated to be safe and effective for the treatment of especially early-stage lung cancer (13). On contrary, it is indication and outcomes for other lung pathologies in children like cystic diseases or congenital abnormalities have not been well-established in the literature, yet. To our knowledge, this is one of the first studies in the literature, which has an in-depth outcome analysis of VATS in pediatric population with different indications.

Hence, the purpose of this study is to analyze the clinical and histopathological results of VATS in pediatric population and try to understand its efficacy and potential complications in a minimum 1-year of follow-up period.

\section{Materials and Methods}

\section{Study Population}

All patients undergoing an elective lobectomy or segmentectomy with VATS at the Pediatric surgery department of our university hospital between 2006 and 2016 were identified and retrospectively enrolled in the study population. The indication for VATS was concluded after proper medical preparation with consultations to the relevant departments and radiological analysis including chest-computed tomography (CT).
Patients were excluded if they underwent resection other than lobectomy or segmentectomy or they did not have regular follow-up visits or have prior chest surgery history. Patients who did not have a preoperative chest CT available for the analysis also were excluded from the study group. The medical charts of the enrolled patients were evaluated and the data of the patients who met the inclusion criteria were extracted for the final analysis. Finally, a total of 26 patients were evaluated for the final analysis.

The protocol of the study was approved by the institutional review board of our institution (12-716-17). Informed consent of the operation was obtained from all patients before surgery.

\section{Surgical Procedure}

All VATS were performed by two investigators who had considerable experience in pediatric thoracoscopic surgery. All procedures were conducted in a lateral decubitus position that was previously described in the literature. Selective one-lung ventilation was used in some older children and adolescents to allow ipsilateral lung collapse. In some children, an endotracheal tube was inserted into the contralateral main bronchus to achieve ipsilateral lung collapse.

In short, VATS was carried out using a rigid 5-mm-diameter thoracoscopy (30 degrees, Olympus corp., Lake Success, N.Y.) through three or four trocar ports $1.0-\mathrm{cm}$-long skin incision). One chest tube was placed at the end of the procedure, but this tube was removed if no air leak was recognized and the daily output was less than $200 \mathrm{~mL}$. For the excision of the hydatic cyts, an endobag was used. After freeing the lung segment in which the cyts was present, the segment was put into an endobag and the endobag was carried out thorugh the working portal.Patients with no main complications were discharged from the hospital.

\section{Study Parameters}

Data from each patient were collected by a blinded investigator regarding the patient demographics including gender and age, medical history including indications for VATS and past surgical history, preoperative investigations, comorbidities, intraoperative findings, operative data, postoperative course including any morbidity and mortality. The indications for VATS were grouped in three categories including congenital malformations, cystic pathologies and malignencies. The total duration of surgery and the lobectomy or segmentectomy regions were recorded for each patient and complications were noted, if any. In the postoperative period, duration of the hospital stay and duration of the chest tube application were recorded for each patient. All patients had histopathological examination and their pathology reports were also recorded for the final outcome analysis. 


\section{Results}

From 2006-2016, a retrospective review was done for 33 pediatric patients who underwent lobectomies and segmentectomies. Twenty-six patients underwent thoracoscopic approach while remaining seven were managed by thoracotomy. In the thoracoscopy group there were 13 boys (50\%) and 13 $(50 \%)$ girls. The ages of the patients were between 14 days and 17 years (median=12 months). The prediagnosis before VATS were congenital pulmonary airway malformation - CPAM (10 patients), pulmonary sequestration (four patients), neoplasms (two patients one with benign and one with malignant), cyst hidatid of lungs (two patients) (Figure 1), spontaneous pneumothorax (three patients who had bullous lesion at pulmonary lobe) (Figure 2), bronchogenic cyst (five patients). There were only two segmentectomies (one left posterobasal and one right apical segment). The remaining 24 patients had undergone lobectomies. Only two patients had multilobectomies. The reasons for these multi-lobectomies were cyst hidatid (right and left lower lobes) and CPAM (bilobectomy superior), respectively.

In four patients (4/26), conversion to thoracotomy was required (15.4\%); because of inadequate exposure due to bleeding. In children undergoing thoracoscopic surgery, blood transfusion was not required during or after the operation. The operation time was between 45 and 210 minutes (mean: 107 mins). Chest tube was placed all of the patients and removed on between postoperative 2-10 days (median=4 days) and the average discharge time was 5.7 days (3-12 days). No mechanical ventilation was required after surgery in any patient. Pathologic examination revealed CPAM in 13 patients, pulmonary

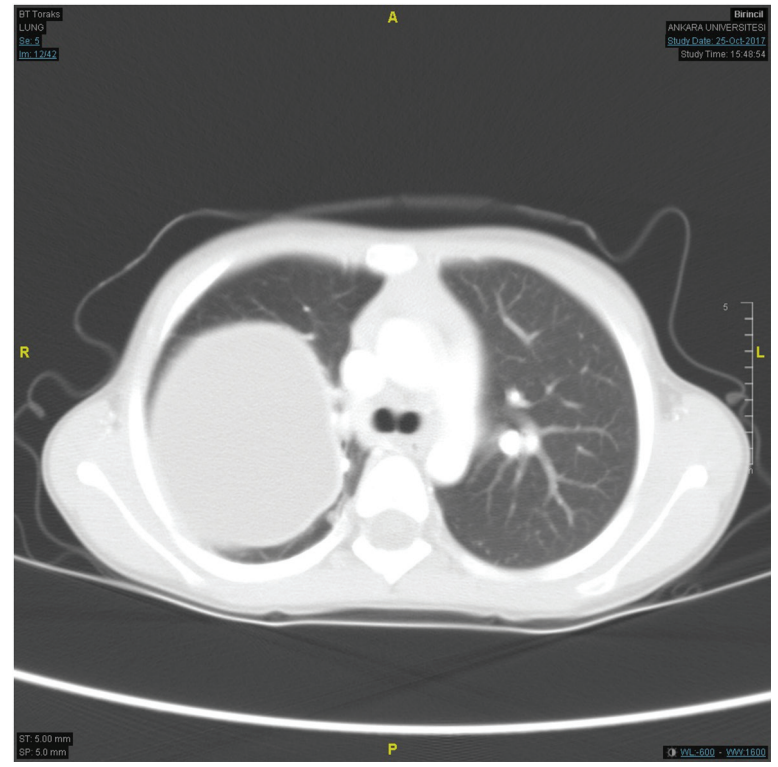

Figure 1: CT scan of cyst hydatid

CT: Computed tomography sequestration in five patients, bullous lesions in two patients, hydatid cystic lesion in two patients, Ewing's sarcoma in two patients, bronchogenic cyst in one patient and Wilms tumor metastasis in one patient. No bronchopleural air leak requiring intervention was seen in any patient.

Thoracotomy was performed in seven patients. There were six males and one females. Five lobectomies (three left upper lobes, one right middle lobe and one right lower lobe) and segmentectomies (two right lower lobes) and two segmentectomies were performed. The median age was 50 months ( 1 month-12 years). Median chest tube removal was 5 days (3-12 days). Median length of hospital stay was and 10 days (4-18days). Results are showed in Table 1.

\section{Discussion}

In the literature, the effectiveness and safety of VATS in pediatric population is still a matter a debate and the guides for clear-cut indications is still lacking $(14,15)$. Though, VATS has been proved to be used widely in many circumstances, the outcomes for pediatric population has to be analyzed with longterm follow-ups (16-18). With increasing experience of VATS, more case series with larger study groups has been published in the literature $(5,19,20)$. Hence, the current study is one of the first studies in the literature with 10 years of experience of VATS and a minimum 1-year of follow up.

As previously mentioned, lobectomy by VATS has been controversial in terms of its indications, but its efficacy of managing lung diseases in adult and pediatric population except malignant diseases is well established in the literature (21). In 2003 studies by Albanese et al. (22) and Rothenberg

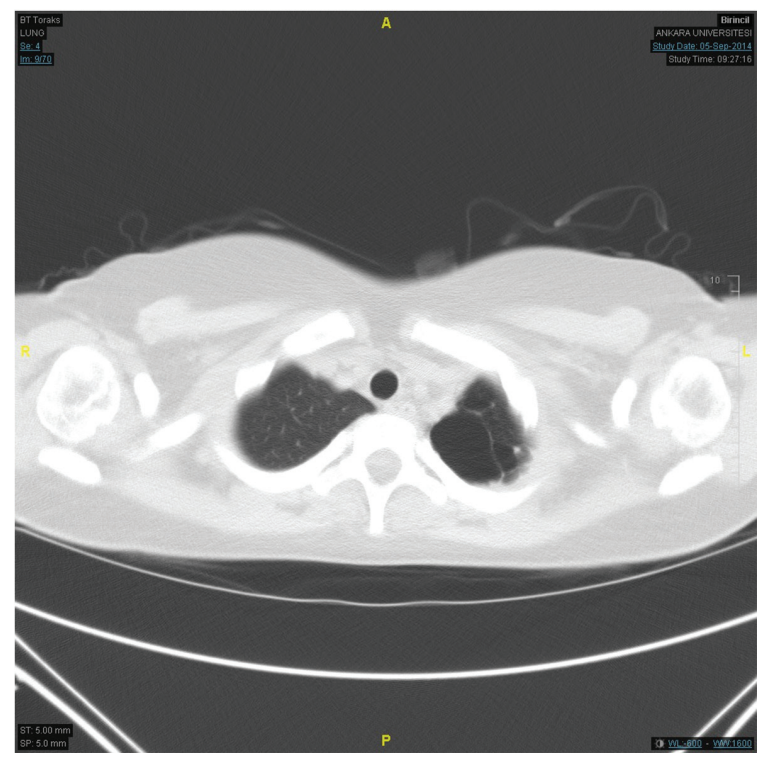

Figure 2: CT scan of spontaneus pneumothorax CT: Computed tomography 


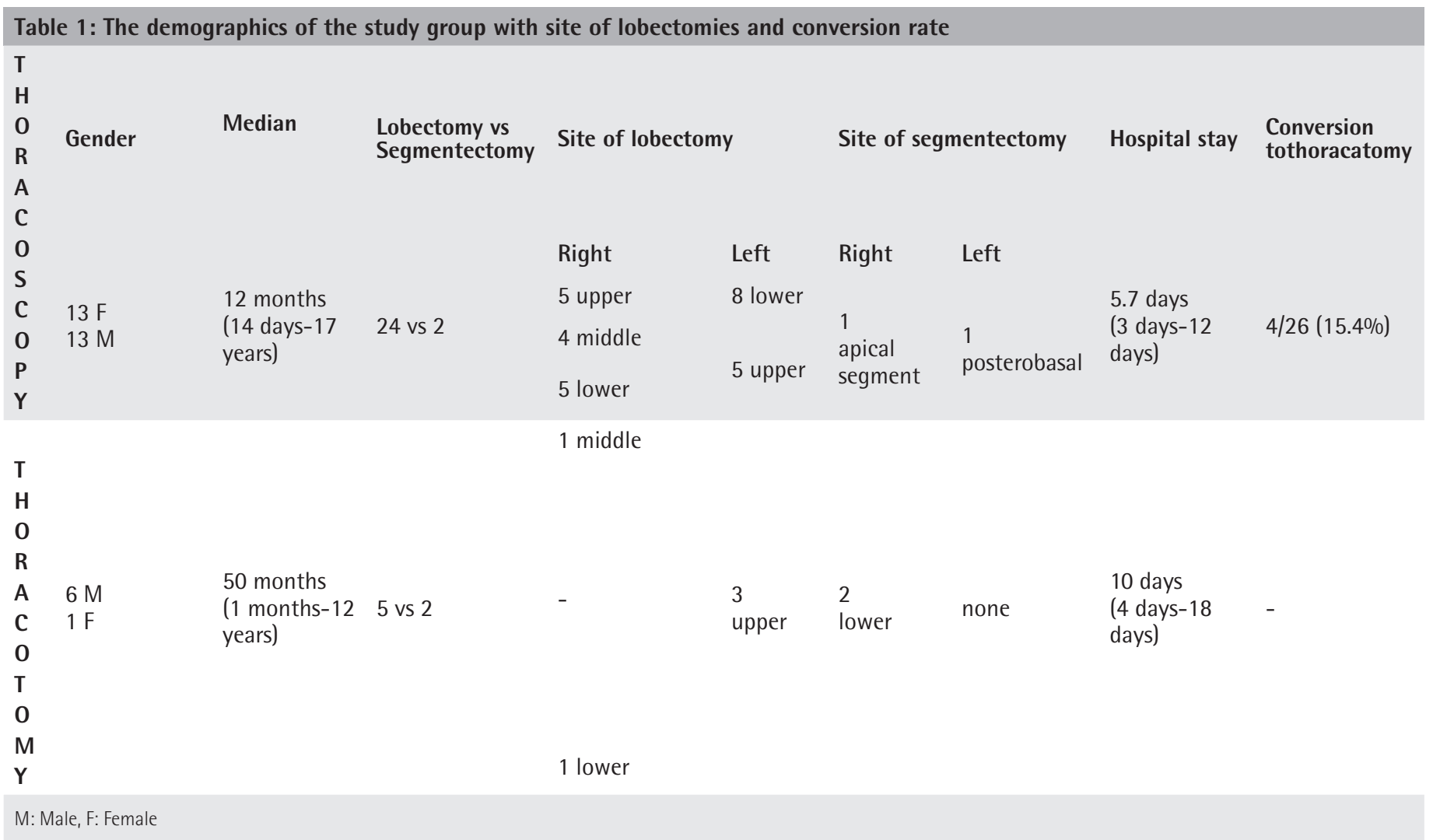

(23) it was reported that VATS lobectomy had enough safety and efficacy of even in infants and children, whose diagnosis included pulmonary sequestration, congenital adenomatoid malformation, severe bronchiectasis, congenital lobar emphysema and malignancy. The authors who is Seong et al. (24), emphasized the prevention of the inherent morbidity of a major thoracotomy incision and a reduction in pain resulting in early recovery with a short hospitalization. Our indications in the current study are consistent with the literature. The indications of VATS in pediatric population in the current study have a wide and safe margin ranging from congenital malformations and cystic pathologies to most of the thoracal malignencies. Our experience concerning the pros and cons of VATS lobectomy in pediatric population, suggested the advantages of the procedure in terms of the function and healing degree over conventional thoracotomy. Therefore, we believe that more training on technical aspects of VATS should be performed with more clinical experience in order to increase the indicative effectiveness of this surgical procedure.

The conversion to thoracotomy from VATS is one of the most commonly encountered problems of this minimal-invasive surgical approach. In the literature, very few studies have specifically examined VATS conversions, especially predictors of conversion (25). The scarce conversion data in the literature revealed that, different case series had different conversion rates ranging from as low as to $4 \%$ to as high as $30 \%$ with an average percentage of 20. It is generally accepted in the literature that most commonly seen reasons for conversion is emergency conditions like as vascular injuries or elective problems due to a technically difficult dissection of a malignant, fibrotic, highly vascular tissue (26). Rothenberg et al. (27) argues that one of the reasons to is bleeding for conversion thoracotmy because of the large pulmonary vessels and the small chest cavity. In a study by Gazala et al. (26), a classification system for the VATS conversion for lobectomy surgeries has been proposed. Seong et al. (24) reported to reasons of conversion thoracotomy which is lower body weight, failure of single-lung ventilation and preoperative pneumonia history. The authors have classified conversions into vascular injuries; anatomic reasons, such as adhesions, bulky, or sticky lymph nodes; and technical issues, such as stapler misfire or equipment failure. The analysis of this classification of conversion revealed that $41 \%$ of conversions were due to vascular injuries, and only $9 \%$ of conversions were due to bulky or sticky lymph nodes. Although their reported mortality was low, the length of stay was longer for patients requiring conversion to thoracotomy (26). On contrary, in another study by Park (28) analyzing the unplanned conversions for VATS lobectomy, over $40 \%$ of conversions was due to hilar nodal fibrosis and hilar adhesions. Similar to Gazala et al. (26) study, this conversion to thoracotomy was associated with increased operative time and length of stay. In our study, the conversion rate was $15.4 \%(4 / 26)$ which is below the average 
rate of the literature. In the current study, all 4 conversions were due to excessive bleeding and inadequate exposure, which is consistent with the literature. All these four cases also had prolonged operation time and hospitalization period, which is also consistent with the literature. We believe that, our low conversion rate in comparison with the literature is due to the 10 -years of experience for VATS. So, in order to decrease the conversion rate, the surgical skills must be developed with more training.

When we compare our data of thoracotomy and thoracoscopic procedures; independently from underlying disease; hospital stays were longer in thoracotomy group. The chest tube removal time was similar; though the patients in thoracoscopy group did not have a large thoracotomy scar and the risk of musculoskeletal complications that may arise from thoracotomy.

The management of malignancy with VATS has been a controversial issue in the literature due to high complication rates and morbidity $(14,20)$. The efficacy of multi-modal treatment options including prospective chemotherapies and radiotherapy with surgical treatment for mediastinal malignant tumors seems to support the efficacy of the thoracoscopic approach. Nevertheless, there is still no gold standard approach for these thoracal or mediastinal masses in the pediatric population. In a study by Smith et al. (29) the rapid postoperative recovery after VATS was implicated which permits patients to undergo an immediate postoperative chemoradiotherapy in comparison with conventional thoracotomy. In the literature, it is also generally accepted that a tumor size of less than $8 \mathrm{~cm}$ in diameter without metastasis is considered to be a prognostic factor of effective VATS for the pediatric population (29). So, it is generally accepted in the literature that, a tumor size of greater than $10 \mathrm{~cm}$ is considered not suitable for an effective VATS and the prognosis could be worse for these cases. In our study, only three patients with malignant neoplasms had undergone VATS. One of these patients had malignancy of Wilms tumor metastasis and the other two had Ewings sarcoma. Our VATS experience of 10 years revealed that VATS has a great potential for malignancies in selected pediatric patients. So, consistent with the literature, VATS is a safe and effective approach for these malignant thoracal or mediastinal masses in pediatric population but should be carefully handled in un-experienced surgeons.

\section{Study Limitations}

There are some limitations for the current study. First, this is a retrospective review of case series. An in-depth analysis of these cases prospectively must be performed in future studies. And also, our case series did not have enough number of cases for each indication. So more different cases with more power should be analyzed in order to have more accurate outcomes in future studies.

\section{Conclusion}

VATS is a safe and effective surgical procedure not only for the adults but also for the pediatric population. Although, it seems to have a high conversion rate, in experienced hands, it has low complication rates with faster recovery time especially for the pediatric cases who have malignancies.

\section{Ethics}

Ethics Committee Approval: The protocol of the study was approved by the institutional review board of our institution (12-716-17).

Informed Consent: Informed consent of the operation was obtained from all patients before surgery.

Peer-review: Externally peer-reviewed.

\section{Authorship Contributions}

Surgical and Medical Practices: U.A., G.G., T.A., M.B.K., H.D., A.Y., Concept: E.E., K.B., N.Y.T., Design: U.A, G.G., Data Collection or Processing: K.B., N.Y.T., Analysis or Interpretation: U.A., E.E., G.G., Literature Search: M.B.K., A.Y., Writing: H.D., T.A., U.A., G.G., E.E.

Conflict of Interest: The authors report no proprietary or commercial interest in any product mentioned or concept discussed in this article.

Financial Disclosure: No financial assistance was received to support this study.

\section{References}

1. Baysungur V, Tezel C, Okur E et al. Quality of life assessment six months after lobectomy for lung cancer: video-assisted thoracoscopic surgery versus thoracotomy. Turkish Journal of Thoracic and Cardiovascular Surgery. 2010;19:207-212.

2. Gilbert JC, Powell DM, Hartman GE, et al. Video-assisted thoracic surgery (VATS) for children with pulmonary metastases from osteosarcoma. Ann Surg Oncol. 1996;3:539-542.

3. Yagmurlu A, Aktug T. Video-assisted thoracoscopic surgery (VATS) in the management of complicated pneumonia in children. J Pediatr Surg. 2001;36:1875.

4. Rodgers BM, Moulder PV, DeLaney A. Thoracoscopy: new method of early diagnosis of cardiac herniation. J Thorac Cardiovasc Surg. 1979;78:623-625.

5. Liu HP, Chang CH, Lin PJ, et al. Thoracoscopic management of effusive pericardial disease: indications and technique. Ann Thorac Surg. 1994;58:1695-1697.

6. Kogut KA, Bufo AJ, Rothenberg SS, et al. Thoracoscopic thymectomy for myasthenia gravis in children. J Pediatr Surg. 2000;35:1576-1577.

7. Kraus DH, Saenz NC, Gollamudi S, et al. Pediatric rhabdomyosarcoma of the head and neck. Am J Surg. 1997;174:556-560.

8. Koizumi K, Tanaka S, Haraguchi $\mathrm{S}$, et al. Lobectomy by video-assisted thoracic surgery for primary lung cancer: experiences based on provisional indications. Surg Today. 1998;28:36-40.

9. Spurbeck WW, Davidoff AM, Lobe TE, et al. Minimally invasive surgery in pediatric cancer patients. Ann Surg Oncol. 2004;11:340-343.

10. Crisci $R$, Droghetti $A$, Migliore $M$, et al. Video-assisted thoracic lobectomy for lung cancer in Italy: the 'VATS Group' Project. Future Oncol. 2016;12:911. 
11. Jing $X$, Lin $Y$, Zhang $B$, et al. Video-assisted thoracoscopic lobectomy mitigates adverse oncological effects of delayed adjuvant chemotherapy for nonsmall cell lung cancer patients. J BUON. 2016;21:1524-1529.

12. Samancilar $\mathrm{O}, \mathrm{Akçam} \mathrm{TI}$, Kaya SO, et al. Video-assisted thoracoscopic surgery (VATS) right upper lobectomy for non-small-cell lung cancer with an azygos lobe. Kardiochir Torakochirurgia Pol. 2016;13:373-374.

13. Daniels $\sqcup$, Balderson SS, Onaitis MW, et al.Thoracoscopic lobectomy: a safe and effective strategy for patients with stage I lung cancer. Ann Thorac Surg. 2002;74:860-864.

14. Peng J, An S, Wang HP, et al. Video-assisted thoracoscopic surgery lobectomy for lung cancer versus thoracotomy: a less decrease in SVEGFR2 level after surgery. J Thorac Dis. 2016;8:323-328.

15. Polastri M, Dell'Amore A, Dolci $G$, et al. Dyspnea and Fatigue Following Videoassisted Thoracic Surgery for Pulmonary Lobectomy: Measuring Scales to Optimize the Allocation of Resources. Chin Med J (Engl). 2016;129:21392140.

16. Amore $D$, Curcio $C$. Steps in the development of a VATS lobectomy program. J Vis Surg. 2017;3:104.

17. Sawant A, Mankar H, Chatterjee A, et al. VATS Versus Open Lobectomy: Need for a Prospective Trial. Ann Thorac Surg. 2017;103:690-691.

18. Tcherveniakov $\mathrm{P}$, Bogdan $\mathrm{C}$, Chaudhuri N. Crossing the bridge to VATS lobectomy. Ann R Coll Surg Engl. 2017;99:650-652.

19. Alam NZ, Flores RM. Extended video-assisted thoracic surgery (VATS) lobectomy. Minerva Chir. 2016;71:67-71.

20. Kamel MK, Nasar A, Stiles BM, et al. Video-Assisted Thoracoscopic Lobectomy Is the Preferred Approach Following Induction Chemotherapy. J Laparoendosc Adv Surg Tech A. 2017;27:495-500.
21. Sihoe AD. Uniportal video-assisted thoracic (VATS) lobectomy. Ann Cardiothorac Surg. 2016;5:133-144.

22. Albanese CT, Sydorak RM, Tsao $K$, et al. Thoracoscopic lobectomy for prenatally diagnosed lung lesions. J Pediatr Surg. 2003;38:553-555.

23. Rothenberg SS. Experience with thoracoscopic lobectomy in infants and children. J Pediatr Surg. 2003;38:102-104.

24. Seong YW, Kang $\mathrm{CH}$, Kim JT, et al. Video-assisted thoracoscopic lobectomy in children: safety, efficacy, and risk factors for conversion to thoracotomy. Ann Thorac Surg. 2013;95:1236-1242.

25. Blasberg JD, Seder CW, Leverson G, et al. Video-Assisted Thoracoscopic Lobectomy for Lung Cancer: Current Practice Patterns and Predictors of Adoption. Ann Thorac Surg. 2016;102:1854-1862.

26. Gazala S, Hunt I, Valji A, et al. A method of assessing reasons for conversion during video-assisted thoracoscopic lobectomy. Interact Cardiovasc Thorac Surg. 2011;12:962-964.

27. Rothenberg SS, Middlesworth W, Kadennhe-Chiweshe A, et al. Two decades of experience with thoracoscopic lobectomy in infants and children: standardizing techniques for advanced thoracoscopic surgery. J Laparoendosc Adv Surg Tech A. 2015;25:423-438.

28. Park BJ. Reply to Letter: "Long-term Survival Based on the Surgical Approach to Lobectomy for Clinical Stage I Nonsmall Cell Lung Cancer: Comparison of Robotic, Video-assisted Thoracic Surgery, and Thoracotomy Lobectomy". Ann Surg. 2018;267: e34-e35.

29. Smith TJ, Rothenberg SS, Brooks M, et al. Thoracoscopic surgery in childhood cancer. J Pediatr Hematol Oncol. 2002;24:429-435. 